\title{
Effectiveness of Teacher Professionalism in The Science Process Skills of Students
}

\author{
Hidayah Ina Qodriyani ${ }^{*}$, Suyitno Aloysius ${ }^{2}$, Slamet Suyanto ${ }^{3}$ \\ 1,2,3Biology Education, Graduate School Yogyakarta State University \\ e-mail: inaqodriyani95@gmail.com
}

\begin{abstract}
The scientific ability of students who are under international average standards compels them to continuously improve education quality in Indonesia. The inequality understanding of scientific process skills in districts like in Sragen is worth the attention. Teachers as the education core should be able to professionally develop the scientific process skills of participants. The research aims to determine the professional influence of teachers on the skills, including knowing the profile of the skills, mastery of the skills' aspects. This research is a quantitative descriptive survey. The study was conducted on 198 students and biology teachers. Collecting student data with tests and teachers with questionnaires and interviews. Results show the skills in Sragen categorized as medium to average 19.22 of 32, the highest mastery of the skills' aspects are communicating and predicting, the lowest is identifying variables, collecting and processing data, there is a professional influence of teachers on the skills.
\end{abstract}

Keywords: Science Process Skill, Professional Teacher, Biology Teacher

\section{Introduction}

The quality of education is one of the problems that the Indonesian government has long faced. Control of the quality of education is basically the quality control of human resources in the system (Putra et al., 2015; Puspendik, 2019). Various efforts have been made by the government to improve the quality of education in Indonesia. But the reality is that until now the quality of education in Indonesia is still relatively low. This is based on the fact that the results of the international survey, PISA (Program for International Students Assessment) created by the OECD (Organization for Economic Co-operation and Development) to measure the learning competencies of one of the science skills of students globally in various countries from year to year showed less satisfactory results as in Table 1.

Table 1. Indonesia Score in PISA from 2000-2018

\begin{tabular}{cccccccc}
\hline Years & $\mathbf{2 0 0 0}$ & $\mathbf{2 0 0 3}$ & $\mathbf{2 0 0 6}$ & $\mathbf{2 0 0 9}$ & $\mathbf{2 0 1 2}$ & $\mathbf{2 0 1 5}$ & $\mathbf{2 0 1 8}$ \\
\hline Indonesia & 392 & 395 & 393 & 383 & 382 & 403 & 396 \\
$\quad$ Scores & & & & & & & \\
$\quad$ Ranking & 38 & 38 & 50 & 60 & 64 & 64 & 74 \\
$\begin{array}{c}\text { The number of } \\
\text { Countries }\end{array}$ & 41 & 40 & 57 & 65 & 65 & 72 & 79 \\
\hline
\end{tabular}

Table 2. Indonesia Scores in TIMSS from 2000-2015

\begin{tabular}{cccccc}
\hline Years & $\mathbf{1 9 9 9}$ & $\mathbf{2 0 0 3}$ & $\mathbf{2 0 0 7}$ & $\mathbf{2 0 1 1}$ & $\mathbf{2 0 1 5}$ \\
\hline Indonesia Scores & 435 & 420 & 433 & 406 & 397 \\
Ranking & 32 & 31 & 35 & 40 & 44 \\
The number of & 38 & 46 & 49 & 45 & 49
\end{tabular}

Source : (Utomo et al., 2018)

${ }^{*}$ Corresponding author.

Received 06 January 2020; Accepted 25 August 2020; Available online 01 December 2020

(c) 2020 JPI. All Rights Reserved

Jurnal Pendidikan Indonesia (JPI) | 666 
Not much different conditions are shown in the international survey by TIMSS (Trend in International Mathematics and Science Study) in Table 2 created by the IEA (The International assossiation for the Evaluation of educational Achievement) which measures the skills of science.

TIMSS criteria divide the achievement of the survey into 4 levels, namely low $=400$, medium $=475$, high $=550$ and advanced $=625$ (Eriksson et al., 2019). So, all Indonesia scores in TIMSS from 1999-2015 turned out to always be at a low level.

Based on the data obtained from PISA and TIMSS, it can be concluded that the study results of Indonesian students, especially the understanding of science, are still below the average of international standards. The science learning that has been done today is still not maximally proven from the results of PISA and TIMSS international survey of Indonesia which is ranked low. Research on science skills today focuses more on researching the development of aspects of science process skills in some schools by creating innovations in new teaching materials or multimedia development to support the development of students' science process skills. But the important thing about the core problem of the cause of not maximal development of science process skills in Indonesia is still not much researched. Whereas to optimize the quality improvement of education in Indonesia, it is necessary to know and improve first what is the fundamental or main problem that is currently occurring.

Teachers are one of the success spearheads of government programs to continuously improve the quality of education in Indonesia to be able to compete globally and catch up with other countries as well as PISA and TIMSS survey results. It is teachers who have a leading role in designing learning activities and developing science process skills to their students. Teachers as agents of change have an important role to play in improving the quality of education. Professional teachers are those who are able to improve the quality of their members, have knowledge and commitment to their students, master teaching materials and teaching methods, have the responsibility of monitoring the learning progress of students, and have the ability to think (Putra et al., 2015). Therefore, it is the teacher who plays an important role in the successful development of the science process skills of his students. Science process skills according (Brotherton \& Preece, 1996) in solving problems recorded well in memory.

Facts in the field based on observations in several schools in SMA N Sragen Regency found that not all teachers have developed the science process skills of their students to the maximum. Teachers, especially biology, use conventional learning more and do practical activities with their students only 1-4 times in one semester so that the ability of science skills that students have has not developed optimally.

In line with (Aziz, 2012) focused on concepts, science learning during this time tends to hone aspects of remembering and understanding and less training the science process skills of students in solving problems. So teachers provide more conventional learning materials that must be memorized than to provide practical activities to develop the science process skills of students. These findings are also supported by preliminary studies conducted by researchers in one of the schools in SMA N Sragen Regency, that the learning is done has not optimized students to actively solve problems through the science process skills and caused the learning results to be less than optimal, namely that more than $70 \%$ of students are not completed in the daily replay of biology and have scores below KKM. The fact that occurs in other fields is the uneven value of the UN, especially biology, according (Puspendik, 2019) the range of UN biology values in SMA N Sragen Regency is between 41.39 - 78.92.

The findings, in this field, suggest that the professionalism factor of teachers in teaching is a major factor in the development of students' science process skills, where teachers play a leading role in preparing learning activities for students. Teacher professionalism can continue to develop through several factors such as self-development activities in the form of functional training and collective activities to improve teacher professionalism (MGMP and seminars), scientific publications such as research and certification (Kusnandar, 2011). In line with this, (Sa'diyyah et al., 2016) teach. These factors are assumed to be influential in the professionalism of teacher in developing skill-based learning of science processes.

Therefore, this research aims to know the effectiveness of teacher professionalism towards the skills of the science process, including knowing the skill profile of the student's science process and student's aspect mastery of the science process skills. As a component to 
describe the profile of science process skills that students have also analyzed the relationship of teacher professionalism variables with the skill profile of the science process. As information and evaluation material for the Education Office so that the quality of education can continue to be improved.

\section{Method}

This research uses quantitative descriptive methods with survey methods. The research was conducted at six High Schools in Sragen Regency that were selected based on the length of teaching teachers, namely SMA N 1 Sragen, SMA N 2 Sragen, SMA N 3 Sragen, SMA N 1 Gondang, SMA N 1 Plupuh, SMA N 1 Gemolong. The research's population was X-grade students at six high schools in Sragen Regency and six classmate biology teachers.

Data collection techniques in the form of a confucian test of science process skills in biological matter as many as 32 questions given to X-grade students and interviews and questionnaire sheets. Data analysis technique to know the value of science process skill mastery profile is by analyzing the answer to the question data by manually reviewing the question. If the correct answer gets a score of 1 and if the wrong answer is given a score of 0 . The maximum score obtained is 32 while the minimum score is 0 . Score data obtained later in the average and used to analyze the overall profile of the sample with categories adapted from (Sudiana, 1989).

Table 3. Categories of science process skills profiles

\begin{tabular}{cc}
\hline Category & Science process skills score \\
\hline Low & $0-10.66$ \\
Medium & $10.67-21.33$ \\
High & $21.34-32$ \\
\hline
\end{tabular}

This category is useful for interpreting the mastery level of science process skills of students. While the percentage of mastery of science process skills is calculated by the calculation formula adapted (Purwanto, 2000).

The percentage of grades obtained by students for each aspect of science process skills is grouped into (Purwanto, 2000) as follows.

Table 4. Mastery criteria for every aspect of science process skills

\begin{tabular}{ccc}
\hline No & Percentage (\%) & Criteria \\
\hline 1 & $86-100$ & Very high \\
2 & $76-85$ & High \\
3 & $60-75$ & Medium \\
4 & $55-59$ & Low \\
5 & $\leq 54$ & Very low \\
\hline
\end{tabular}

The results of the science process skills score were analyzed descriptive statistics to get the average score, standard deviation, lowest score, highest score, and number of samples on each study group, especially to see the trends and distribution of the science process skill profile in general. Meanwhile, data on teacher professionalism can be found by comparing the average score scoring the science process profile with the teacher's length of teaching.

\section{Results and Discussions Results}

Science process skills are scientific skills that must be mastered by students in the purpose of developing the thinking and creativity skills of students. The results of research on the science process skills profile of 6 public schools in Sragen Regency are contained in Table 5 . 
Table 5. X-grade science process skills test results in Sragen Regency.

\begin{tabular}{|c|c|c|c|c|c|c|c|}
\hline No & Code & School & $\mathbf{N}$ & $\bar{y} \pm s$ & Max & Min & KPS Category \\
\hline 1 & A & SMAN 1 Sragen & 32 & $23.62 \pm 3.20$ & 30 & 18 & High \\
\hline 2 & B & SMAN 2 Sragen & 32 & $21.90 \pm 2.57$ & 26 & 16 & High \\
\hline 3 & C & SMAN 3 Sragen & 34 & $15.20 \pm 2.18$ & 18 & 11 & Medium \\
\hline 4 & D & SMAN 1 Gondang & 36 & $17.81 \pm 2.81$ & 20 & 14 & Medium \\
\hline 5 & $E$ & SMAN 1 Plupuh & 30 & $15.43 \pm 1.89$ & 18 & 12 & Medium \\
\hline 6 & $\mathrm{~F}$ & SMAN 1 Gemolong & 34 & $21.38 \pm 1.81$ & 24 & 16 & High \\
\hline & & Total & 198 & $19.22 \pm 2.41$ & 30 & 11 & Medium \\
\hline
\end{tabular}

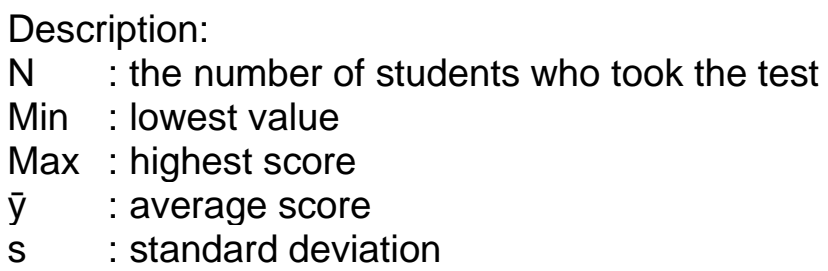

Table 5 describes the X-grade science process skills profile in SMA N Sragen Regency has varying results. A moderate profile of science process skills was shown by an average score of 19.22 out of a total score of 32. Students who scored 30 showed that students had high science process skills, meaning that students had mastered the science process skills, while the students who scored 11 showed the students had moderate science process skills, meaning that the students simply mastered the science process skills. This means biology learning can develop the science process skills of X-grade students, but it is not optimal and evenly distributed because there is a difference in the highest and lowest scores that are quite far from 19. The standard deviation obtained by 2.41 shows that the general profile of science process skills in SMA N Sragen Regency is quite varied, seen in SMA A has a higher standard deviation than other high schools, which means that students in SMA A are more mastery of science process skills than students from other schools.

The next research data is about the percentage of mastery of each aspect of the science process skills possessed by students in grade X SMA N Sragen Regency is found in table 6.

Table 6. Presentase mastery of various aspects of science process skills class X SMA N in Sragen Regency.

\begin{tabular}{|c|c|c|c|c|}
\hline No & Code & Aspects & Mastery Percentage (\%) & Category \\
\hline 1. & A. & Observing & 76 & High \\
\hline 2. & B. & Communicating & 83 & High \\
\hline 3. & C. & Classifying & 62 & Medium \\
\hline 4. & D. & Taking measurements & 76 & High \\
\hline 5. & E. & Concluding & 48 & Very low \\
\hline 6. & F. & Predicting & 78 & High \\
\hline 7. & G. & Identifying variables & 43 & Very low \\
\hline 8. & $\mathrm{H}$. & Creating a table & 63 & Medium \\
\hline 9. & I. & Creating a graph & 63 & Medium \\
\hline 10. & J. & $\begin{array}{l}\text { Describing relationships } \\
\text { between variables }\end{array}$ & 76 & High \\
\hline 11. & $\mathrm{~K}$. & $\begin{array}{l}\text { Collecting and processing } \\
\text { data }\end{array}$ & 40 & Very low \\
\hline 12. & L. & $\begin{array}{l}\text { Analyzing the results of the } \\
\text { study }\end{array}$ & 54 & Very low \\
\hline 13. & M. & Compiling hypotheses & 52 & Very low \\
\hline 14. & $\mathrm{~N}$. & Setting operational variables & 76 & High \\
\hline 15. & O. & Compiling experiments & 68 & Medium \\
\hline 16. & P. & Experimenting & 52 & Very low \\
\hline
\end{tabular}




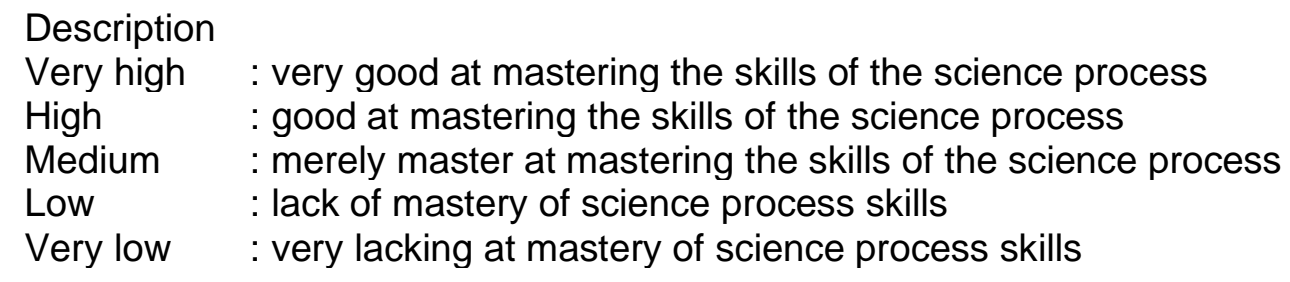

Based on the table of 6 , the highest mastery aspects of the science process skills are found in the aspect of communicating $83 \%$ and predicting $78 \%$. This proves that students are good at mastering the science process skills in the aspects of communicating and predicting. While the lowest mastery of aspects of the science process skills is found in the aspect of identifying variables $43 \%$, collecting and processing data $40 \%$. This means that students are very lacking in mastering the science process skills in the aspect of identifying variables, collecting and processing data.

Further research data is about the influence of teacher professionalism on the ability of the science process skills of its students in table 7 .

Table 7. The influence of teacher professionalism on science process skills of class X SMA N in Sragen Regency

\begin{tabular}{lccccccc}
\hline $\begin{array}{c}\text { Code } \\
\text { Time }\end{array}$ & $\begin{array}{c}\text { Teaching } \\
\text { Graduates }\end{array}$ & $\begin{array}{c}\text { Staffing } \\
\text { Status }\end{array}$ & $\begin{array}{c}\text { Number } \\
\text { of } \\
\text { Trainings }\end{array}$ & MGMP & $\overline{\mathbf{y}} \pm \mathbf{s}$ & $\begin{array}{c}\text { KPS } \\
\text { Category }\end{array}$ \\
\hline A & 28 & Master & Civil Servants & 12 & every & $23.62 \pm 3.20$ & High \\
B & 24 & Bachelor & Civil Servants & 9 & month & $21.90 \pm 2.57$ & High \\
F & 21 & Bachelor & Civil Servants & 8 & routine & $21.38 \pm 1.81$ & High \\
D & 17 & Bachelor & Civil Servants & 6 & & $17.81 \pm 2.81$ & Medium \\
E & 9 & Bachelor & $\begin{array}{c}\text { Non-Civil } \\
\text { Servants }\end{array}$ & 3 & & $15.43 \pm 1.89$ & Medium \\
C & 5 & Bachelor & $\begin{array}{c}\text { Non-Civil } \\
\text { Servants }\end{array}$ & 2 & & $15.20 \pm 2.18$ & Medium \\
& & & & & & & \\
\hline
\end{tabular}

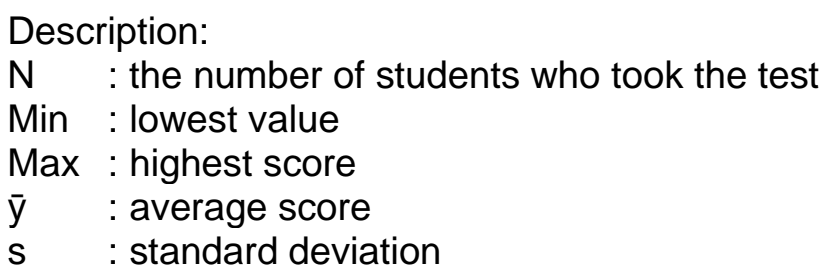

Table 7 shows teachers who have been teaching for more than 20 years, namely SMA A, $\mathrm{B}, \mathrm{F}$ have students with high category of the science process skills, while teachers who have taught less than 20 years of high school D, E, C have students with medium category of the science process skills. Teacher professionalism is influenced by the teacher's length of teaching, the longer teaching will be the more often teachers participate in activities in the form of education, training and MGMP, and the more experience they have that will also impact the learning process in the classroom.

\section{Discussion}

Based on the results of the study obtained the fact that the profile of science process skills in SMA N Sragen Regency has varying results such as those found in Table 5, there is SMA $N$ which has high category science process skills such as in SMA $A, B$ and $F$ and medium category such as in SMA C, D, and $\mathrm{E}$. The fact that there is SMA N with science process skills with medium category should be a concern. This is because according to the theory of cognitive development Piaget, high school students are already at the formal operational stage. This means that students have been able to think abstractly about developing their ideas to solve 
biological problems (Sund \& Trowbridge, 1973) But the fact in the field is that not all schools have students with uniformly distributed science process skills. Whereas the science process skill is especially important in the success of learning.

Science process skills have a positive relationship to students' learning outcomes. As research has been done by (Sari et al., 2017) about the contribution of science process skills to the study results shows positive results. This means that by developing science process skills in students, the learning outcomes of students will also improve. In line with (Siswono, 2017) concept mastery of students. According (Rauf et al., 2013) students will be more optimal. Based on (Rahmasiwi et al., 2015) explained that biology teaching conducted by developing science process skills obtains higher test and diagnostic scores than conventional biology teaching. Based on this, these science process skills are important to be instilled and developed by teachers to students so that the learning results of students can be optimal. According (Lightburn \& Fraser, 2007) science process skills are one of the important factors that influence the learning outcomes of students. The results of research on uneven aspects of the science process skills of students are due to the ability of teachers in various schools that are uneven as well.

Teachers teach more concepts in the learning process through the transfer of knowledge and the provision of examples that tend to be memorized by students so that students cannot develop their science process skills to the maximum (Juhji, 2016) This is in accordance with the researchers' findings regarding teacher habits in some high schools $\mathrm{n}$ Sragen districts that use more conventional methods in learning activities.

The highest mastery of aspect of science process skills in SMA N Sragen Regency as found in Table 6 is in communicating skills and predicting skills. According (Rezba et al., 2007) divided into two, namely basic and integrated science process skills. Basic process skills include observing, predicting, concluding, grouping, communicating, and measuring skills. So, based on Rezba's opinion of communicating and predicting skills, both enter basic science process skills. Both aspects are based on the results of the research contained in Table 6 being the highest mastery of aspect of the science process skills of Sragen Regency high school students. This is because basic science process skills have been given to students from elementary school to high school so that students are accustomed to using these skills. This is in accordance with (Khairunnisa et al., 2020) science process skills are obtained not only in a short time but soft skills are obtained from habituation that is often done in daily learning. Based on the results of conducted interviews, teachers' conventional learning methods end with discussion and presentation activities. This makes the communicating and predicting skills of students in SMA N Sragen Regency is stronger embedded so as to obtain the highest results in research such as those found in Table 6 because of the habituation that teachers have done.

The lowest mastery of aspect of science process skills in SMA N Sragen Regency as found in Table 6 is in the skill of identifying variables and collecting and processing data. Integrated science process skills include identifying variables, hypothesize, collecting and processing data, analyzing investigations, tabulating data, identifying variables, planning and conducting investigations (Rezba et al., 2007). It means the skills of identifying variables as well as collecting and processing data included into integrated science process skills. Integrated science process skills are higher in level than basic science process skills. According (Udin et al., 2013) students. Therefore, this skill has not developed to the maximum in high school students due to the lack of habituation that teachers do in instilling integrated skills into their students. Based on the results of the interview, the practice activities conducted on average have been equipped with a practicum manual from the publisher, and the students can just to conduct in practical activities according to the guidelines of the book, so the ability to distinguish variables in students is still less than optimal. As for the skills of collecting and processing data still fall into the low category because in practical activities teachers used to divide students in the form of groups so tend to rely only on other group members in collecting or processing data, therefore these skills are less likely to possessed by students. High school students should have basic and integrated science process skills evenly because students should have science process skills provided by teachers since elementary school level and developed until now. But the facts in the field found an understanding of the skill aspects of the basic and integrated 
science process skills that have not been evenly distributed so that it needs improvement from various related parties.

The process of (Suhardi, 2013) a system whose components are inseparable namely raw input (students), instrumental inputs (curriculum, teachers, learning resources, media, methods, learning infrastructure), environmental and output (external results). Based on the expert opinion, the role of teachers is one of the important parts in influencing the ability of students, including the ability in the science process skills. As the results can be Table 7 that there is a finding that the professionalism of teachers plays a role in the profile of the science process skill of their students. Teachers with longer teaching time will have many experiences such as training experience, MGMP and staffing status as civil servants as in Table 7. More and more experience will make teachers more skilled and innovative in learning activities so that the science process skills of the students are also well developed as seen in Table 7, which teachers who have long teaching above 20 years turn out to have students with high category of science process skills and teachers who have long teaching under 20 years have students with medium category of science process skills.

According (Smylie, 1997) improving student achievement. This demonstrates the importance of developing teacher professionalism in order to be able to creatively motivate and strive to continuously improve and develop the students' skills. This research is in line with (Supovitz \& Turner, 2000) given professional development within 60 hours - 120 hours, the result of which was the development of teacher professionalism effectively affecting the performance of students compared to students from teachers who were not included in the development program. The professionalism of teachers can influence the teaching of science in American schools. In another study (Supovitz et al., 2000) (160 hours) changed teacher's teaching habits and had a positive impact on the science skills and skills that students had.

Based on the results of the research that has been done, the professionalism of teachers has a positive influence on the development of the science process skills of students. Intensive development of teacher professionalism such as participation in training, district MGMP activities, etc. can improve the performance of teachers' ability to teach in the classroom which certainly has a positive impact on the ability of students. Teachers have a very important key role in education, so the implementation and innovation of learning provided by teachers has a huge impact for students ((Hamka et al., 2013). As with the opinion of (Hakim, 2015) 21st Century requires teachers who have high qualifications, skills, creativity, critical thinking, communicative competence, and collaboration so that the quality of education can continue to improve. According to (Hamka et al., 2013) revitalization of learning needs to continue to be done in order for learning to return as ideally. Therefore, the Education Office which has authority in improving the quality of teachers needs to revitalize so that the quality of education can develop better by improving the professionalism of teachers, so as to compete with other countries.

\section{Conclusion}

Based on the results of the research, it can be concluded that the profile of science process skills of high school students in Sragen Regency belongs to a medium category with an average score of 19.22 out of a total score of 32, the highest mastery of aspect of the science process skills of X-class high school students in Sragen Regency is ability to communicate and predict while the lowest aspects are identifying variables and collecting and processing data, there is an influence of teacher professionalism on science process skills. The advice in this study is aimed at teachers and the government of Sragen Regency which is expected to be a reference material so that the science process skills of students can be more optimal, and the government is able to improve training for teachers to develop the professionalism and support the success of teachers in the classroom.

\section{References}

Aziz, H. A. (2012). Karakter Guru Profesional. Al-Mawardi Prima.

Brotherton, P. N., \& Preece, P. F. W. (1996). Teaching science process skills. International Journal of Science Education, 18(1), 65-74. https://doi.org/10.1080/0950069960180106 
Eriksson, K., Helenius, O., \& Ryve, A. (2019). Using TIMSS items to evaluate the effectiveness of different instructional practices. Instructional Science, 47(1), 1-18. https://doi.org/10.1007/s11251-018-9473-1

Haji, S., Yumiati, Y., \& Zamzaili, Z. (2018). Analisis Kesulitan Siswa dalam Menyesaikan SoalSoal PISA (Programme for International Student Assessment) di SMP Kota Bengkulu. Jurnal Pendidikan Matematika Raflesia, 3(2), 177-183. https://doi.org/10.33449/jpmr.v3i2.7522

Hakim, A. (2015). Contribution of competence teacher (pedagogical, personality, professional competence and social) on the performance of learning. The International Journal of Engineering and Science, 4(2), 1-12. https://www.academia.edu/download/36989616/A42301012.pdf

Hamka, L., Asmawati, A. A., Muhiddin, P., \& Rachmayani, A. (2013). Kompetensi Profesional Guru Biologi Sekolah Menengah Atas Negeri di Kota Makassar. Bionature, 14(1). https://ojs.unm.ac.id/bionature/article/view/1444

Juhji, J. (2016). Peningkatan keterampilan proses sains siswa melalui pendekatan inkuiri terbimbing. Jurnal Penelitian Dan Pembelajaran IPA, 2(1), 58-70. http://dx.doi.org/10.30870/jppi.v2i1.419

Khairunnisa, K., Ita, I., \& Istiqamah, I. (2020). Keterampilan Proses Sains (KPS) Mahasiswa Tadris Biologi pada Mata Kuliah Biologi Umum. BIO-INOVED: Jurnal Biologi-Inovasi Pendidikan, 1(2), 58-65. http://dx.doi.org/10.20527/binov.v1i2.7858

Kusnandar. (2011). Guru Profesional. Rajawali Press.

Lightburn, M. E., \& Fraser, B. J. (2007). Classroom environment and student outcomes among students using anthropometry activities in high-school science. Research in Science \& Technological Education, 25(2), 153-166. https://doi.org/10.1080/02635140701250576

Purwanto, M. N. (2000). Prinsip-Prinsip Dan Teknik Evaluasi Pengajaran. PT Remaja Rosdakarya

Puspendik. (2019). Laporan Hasil Ujian Nasional. https://hasilun.puspendik.kemdikbud.go.id

Putra, N. A. R., Abdurrahman, A., \& Suana, W. (2015). Pengaruh Keterampilan Proses Sains dan Sikap IImiah terhadap Pemahaman Konsep IPA Siswa SMP. Jurnal Pembelajaran Fisika, 3(4). http://jurnal.fkip.unila.ac.id/index.php/JPF/article/view/8861

Rahmasiwi, A., Santosa, S., \& Sari, D. P. (2015). Improving Student's Science Proces Skill in Biology Through The Inquiry Learning Model in Grade XI MIA 9 (ICT) SMA Negeri 1 Karanganyar Academic Year 2014/2015. Proceeding Biology Education Conference: Biology, Science, Enviromental, and Learning, 12(1), 428-433. https://jurnal.uns.ac.id/prosbi/article/view/6958

Rauf, R. A. A., Rasul, M. S., Mansor, A. N., Othman, Z., \& Lyndon, N. (2013). Inculcation of science process skills in a science classroom. Asian Social Science, 9(8), 47-57. https://doi.org/10.5539/ass.v9n8p47

Rezba, R., Mcdonnough, J. T., Matkins, J. J., \& Sprague, C. (2007). Science process skills. Hunt Publishing Company.

Sa'diyyah, M., Subali, B., \& Paidi, P. (2016). Kemampuan Berpikir Divergen dalam Keterampilan Proses Sains Peserta Didik SMA Negeri di Kabupaten Kulon Progo pada Mata Pelajaran Biologi Ditinjau Berdasarkan Latar Belakang Pendidikan Guru. Pend. Biologi-S1, 5(7), 38-49. https://eprints.uny.ac.id/31050/1/Ana\%20Fitri\%20Apriliyani.pdf

Sari, I. N., Azwar, I., \& Riska, R. (2017). Kontribusi keterampilan proses sains siswa terhadap hasil belajar siswa pada materi wujud zat dan perubahannya. Jurnal Pendidikan Informatika Dan Sains, 6(2), 257-266. http://dx.doi.org/10.31571/saintek.v6i2.651

Siswono, H. (2017). Analisis Pengaruh Keterampilan Proses Sains Terhadap Penguasaan Konsep Fisika Siswa. Momentum: Physics Education Journal, 1(2), 83-90. 


\section{https://doi.org/10.21067/mpej.v1i2.1967}

Smylie, M. A. (1997). From bureaucratic control to building human capital: The importance of teacher learning in education reform. Arts Education Policy Review, 99(2), 35-38. https://doi.org/10.1080/10632919709600769

Sudiana, N. (1989). Dasar-Dasar Proses Belajar Mengajar. PT Sinar Baru Algensindo.

Suhardi. (2013). Pengembangan Sumber Belajar Biologi. UNY Press.

Sund, R. B., \& Trowbridge, L. W. (1973). Teaching Science By Inquiry In The Secondary School. Merrill Publishing Company.

Supovitz, J. A., Mayer, D. P., \& Kahle, J. B. (2000). Promoting inquiry-based instructional practice: The longitudinal impact of professional development in the context of systemic reform. Educational Policy, 14(3), 331-356. https://doi.org/10.1177\%2F0895904800014003001

Supovitz, J. A., \& Turner, H. M. (2000). The effects of professional development on science teaching practices and classroom culture. Journal of Research in Science Teaching: The Official Journal of the National Association for Research in Science Teaching, 37(9), 963-980. TEA6\%3E3.0.CO;2-0 https://doi.org/10.1002/1098-2736(200011)37:9\%3C963::AID-

Udin, M., Arsyad, M., \& Khaeruddin, K. (2013). Peningkatan Keterampilan Proses Sains Melalui Model Pembelajaran Berdasarkan Masalah Pada Siswa Kelas SMA 14 Makassar. Jurnal Pendidikan Fisika, 1(2), 139-148. https://doi.org/10.26618/jpf.v1i2.197

Utomo, A. P., Yuana, K., Narulita, E., Fikri, K., \& Wahono, B. (2018). Students' errors in solving science reasoning-domain of trends in international mathematics and science study (TIMSS). Jurnal Pendidikan IPA Indonesia, 7(1), 48-53. https://doi.org/10.15294/jpii.v7i1.11352 